\title{
TINJAUAN STUDI PENDIDIKAN DI SEKOLAH API KREATIF BANDUNG
}

\author{
Oleh: \\ Fadhilah Hidayatullah \\ (Dosen FKIP Program Studi Pendidikan Sendratasik Universitas PGRI Palembang)
}

\begin{abstract}
Abstrak
Api Kreatif merupakan sekolah yang menerapkan kegiatan berkreativitas melalui pembelajaran dengan seni. Menghasilkan tingkat kreativitas anak dalam berfikir untuk berkarya, sehingga anak akan peka terhadap permasalahan di lingkungannya. Tujuan penulisan artikel ini adalah untuk membahas konsep dari pendidikan sekolah Api Kreatif, yang menerapkan model pembelajaran secara khusus. Pembahasan yang di deskripsikan merupakan hasil riset dari sebuah penelitian di sekolah Api Kreatif Bandung. Tujuan dari penelitian ini adalah untuk mengetahui operasional pendidikan di sekolah Api Kreatif, serta konsep pembelajarannya. Maka dari itu, akan menjadi bahan kajian yang akan dimaknai untuk dunia pendidikan terhadap anak. Metodologi yang di gunakan dalam penelitian ini yakni tekhnik wawancara, dokumentasi, dan studi lapangan. Pendidikan Api Kreatif melalui kegiatan pembelajaran yang meliputi instruksi; mengingat, mengarang, dan mengekspresikan. Sehingga menimbulkan penemuan konsep pembelajaran mengenai mengingat dengan mengasah rasa ingin tahu, mengarang dengan konsep mengolah imajinasi, serta kegiatan mengekspresikan menghasilkan konsep dalam merefleksikan imajinasi. Kegiatan pola dari konsep pembelajaran tersebut yang disebut dengan model pembelajaran yang kreatif, menimbulkan hasil pendidikan yang merujuk pada kejujuran, kedisiplinan, serta rasa menghargai, tanggung jawab, dan percaya diri yang kuat. Berangkat dari makna pendidikan tersebut, semua yang berkaitan pada kegiatan mengingat, mengarang, dan mengekspresikan. Namun perlu didukung oleh segala aspek yang masih minim, yakni tenaga pengajar, siswa, serta sarana dan prasarana. Dengan demikian sekolah akan jauh lebih menghasilkan pendidikan yang lebih baik dan produktif.
\end{abstract}

Kata kunci: Pendidikan, Api Kreatif.

\section{A.PENDAHULUAN}

Pendidikan dapat dikategorikan antara lain; pendidikan formal, informal, dan non formal. Pendidikan formal dilaksanakan oleh pemerintah maupun kelompok masyarakat, seperti PAUD, TK, SD, SMP, SMA, serta Perguruan Tinggi. Sedangkan pendidikan informal yang memiliki ruang lingkup lebih kecil yakni pendidikan dilingkungan rumah tangga, antara orang tua terhadap anaknya. Pendidikan non formal dilaksanakan di tengah masyarakat dengan program yang berdasarkan kesepakatan suatu kelompok tertentu, sehingga terbentuk suatu lembaga pendidikan dengan sebutan "Pendidikan Luar Sekolah" (PLS). Namun tentunya semua jenis pendidikan tersebut untuk menyalurkan sesuatu 
sehingga menjadi sebuah pengetahuan yang diberikan. Disamping pengetahuan, juga sangat diperlukan terhadap anak didik untuk mendapatkan akar pendidikan untuk memumpuni akhlak dan karakter pada anak, sehingga menjadi pondasi yang kuat untuk menyeimbangi lingkungan pada profesinya kelak.

Perlunya pendidikan diberikan dan disalurkan terhadap anak dan generasi bangsa agar membentengi karakter anak sehingga untuk memperkuat jati diri bangsa. Maka dari itu diperlukan pendidikan dasar untuk memumpuni anak melalui dasar dan akarnya suatu pendidikan. Akar pendidikan dimaksudkan untuk memberi stimulan terhadap anak agar mendapatkan dasar sesuatu yang mengasah dan membuat peka terhadap lingkungan, sehingga mampu untuk melakukan sesuatu terhadap tanggungjawabnya kelak. Sehingga dalam hal ini sangat behubungan sekali dengan salah satu lembaga PLS yakni Api Kreatif.

Api kreatif merupakan PLS yang didirikan pada hari Minggu, 05 Mei 2013 di jalan Terusan Suka Mulya, nomor 1 (satu) di rumah Api Kreatif. Api kreatif diambil dari singkatan "akar pendidikan kreatifitas", dengan makna pendidikan yang berbasis pada pendidikan seni, sehingga kurikulumnya juga demikian, mencakup proses pendidikan yang berbasis pada pendidikan seni. Proses pembelajarannya dilaksanakan dengan tema dan media yang bebas, namun tetap berpedoman dengan suatu kurikulum Api Kreatif yang telah di tentukan.

Api Kreatif merupakan sekolah yang membelajarkan anak pada lingkungan sekitarnya dengan memaknai dari seluruh proses yang dilakukan. Peserta didik di sekolah ini melakukan sistem pembelajaran yang di atur sesuai dengan waktu yang telah ditentukan. Karena siswa tersebut berbagai macam latar belakang pendidikan, dari tingkatan SD sampai ke tingkat SMP. Sehingga disepakati bahwa pertemuan sekolah tersebut dilakukan setiap hari Minggu pada waktu yang telah ditentukan.

Proses pembelajaran dilakukan dengan mengajarkan seluruh materi pada cabang seni yang berbasis pendidikan seni. Seluruh materi yang disusun merupakan kegiatan peserta didik dalam memaknai dari proses yang akan dihasilkan dari anak tersebut. Namun tidak menutup kemungkinan mendatangkan guru undangan yang terdapat para ahli dibidangnya. Misalnya ahli pada musik, tari, teater, rupa. Sehingga materi yang diberikan tidak begitu diharuskan layaknya sekolah formal yang ada. Melainkan yang menjadi indikator besar adalah bagaimana peserta didik dapat memaknai dari suatu 
proses pembelajaran tersebut. Sehingga pada akhirnya apa yang dipelajari melaui seni, sehingga menjadi dasar dan akar pada dirinya untuk menyongsong hari-hari mereka kedepannya.

Dalam proses pembelajaran berlangsung tentunya memerlukan bagaimana pendekatan yang tepat di dalam memberikan stimulan terhadap anak agar ia dapat merealisasikan dari materi yang di dapat. Sehingga pada akhirnya materi itu menjadi modal yang begitu memengaruhi pada kehidupannya di masa mendatang. Kemudian diharapkan untuk mengembangkan dari kreatifitas masing-masing, sehingga akar dari pola fikir dan imajinasi anaklah yang di olah, dan pada akhirnya anak diharapkan untuk menjadi seorang yang kreatif. Kreatif dalam bidang masing-masing, dengan demikian pembelajaran pada Api Kreatif ini lebih mengutamakan siswa untuk melihat secara langsung dalam proses setiap apa yang dilakukan sebagai bahan materi pembelajaran.

Sehingga out pout nya, siswa diharapkan untuk lebih menghargai dari apa yang dilihat. Dengan demikian peneliti memilih tempat penelitian pada pendidikan non formal (PLS) di sekolah Api Kreatif dalam naungan dan pimpinan Jaka Falah, S.Sn., M.Pd., dan Asmadiyanti, S.Sn., M.Pd., dengan alasan karena kurikulum PLS Api Kreatif berbeda dengan kurikulum PLS lainnya, serta belum pernah ditemukan sehingga menarik untuk di teliti. Riwayat dan penomena dari salah satu PLS tersebut, akan di ungkap mengenai pembelajaran dalam satu kali pertemuan beserta indikator dari materi yang disampaikan, sehingga akan membahas permasalahan tentang pendidikan di sekolah Api Kreatif.

\section{Landasan Teoretis}

Pembelajaran pada hakikatnya merupakan suatu proses interaksi antara guru dengan siswa, baik interaksi secara langsung seperti kegiatan tatap muka maupun secara tidak langsung, yaitu dengan menggunakan berbagai media pembelajaran (Rusman, 2013, hlm. 134). Sedangkan Hamalik (2009, hlm. 57), pembelajaran adalah suatu kombinasi yang tersusun meliputi unsur-unsur manusiawi, material, fasilitas, perlengkapan, dan prosedur yang saling mempengaruhi mencapai tujuan pembelajaran. Kemudian menurut Susilana (2007, hlm. 1) Pembelajaran merupakan suatu kegiatan yang melibatkan seseorang dalam upaya memperoleh pengetahuan, keterampilan, dan nilai-nilai positif dengan memanfaatkan berbagai sumber untuk belajar. 
Mager (dalam Hamzah dkk, 2010, hlm. 66), mengatakan tujuan pembelajaran adalah tujuan prilaku yang hendak dicapai atau yang dapat dikerjakan oleh siswa pada kondisi dan tingkat kompetinsi tertentu. Sedangkan yang dikemukan oleh Dejnozka, dkk (dalam Hamzah dkk, 2010, hlm. 66), bahwa tujuan pembelajaran adalah suatu pernyataan spesifik yang dinyatakan dalam prilaku atau penampilan yang diwujudkan dalam bentuk tulisan untuk menggambarkan hasil belajar yang diharapkan. Kemudian menurut Percival (dalam Hamzah dkk, 2010, hlm. 66), tujuan pembelajaran merupakan suatu pernyataan yang jelas dan menunjukkan penampilan atau keterampilan siswa tertentu yang diharapkan dapat dicapai sebagai hasil belajar. Sehingga Bloom dan Krathwohl (dalam Hamzah dkk, 2010, hlm. 66), memilah taksonomi tujuan pembelajaran kedalam tiga ranah, yaitu; kognitif, afektif, dan psikomotorik.

Secara lebih sempit bahan ajar juga biasanya disebut sebagai materi pembelajaran. Materi pembelajaran dengan demikian dapat dikatakan sebagai program yang di susun guru untuk mengembangkan pengetahuan, keterampilan, dan sikap di susun guru untuk mengembangkan pengetahuan, keterampilan, dan sikap positif terhadap pembelajaran yang diturunkan dari kurikulum yang berlaku (Abidin, Y., 2014, hlm. 263).

Selama proses pembelajaran tidak lepas dari metode, pendekatan, serta media untuk mendukung terlaksananya suatu pembelajaran di kelas. Berikut uraian dari masingmasing rangkaian terciptanya proses pembelajaran tersebut. Proses belajar-mengajar yang baik, hendaknya mempergunakan berbagai jenis metode mengajar secara bergantian atau saling bahu-membahu satu sama lain. Masing-masing metode ada kelemahan serta keuntungannya. Tugas guru ialah memilih berbagai metode yang tepat untuk menciptakan proses belajar-mengajar. Ketepatan penggunaan metode mengajar tersebut sangat bergantung pada tujuan, isi proses belajar mengajar dan kegiatan belajar mengajar (Sudjana, N., 1988, hlm. 76).

Pendekatan dapat diartikan sebagai titik tolak atau sudut pandang kita terhadap proses pembelajaran. Istilah pendekatan merujuk kepada pandangan tentang terjadinya suatu proses yang sifatnya masih sangat umum (Rusman, 2013, hlm. 132). Sedangkan media merupakan wahana penyalur informasi belajar atau penyalur pesan (Hamiyah, N., \& Jauhar, M., 2014, hlm. 259). 
Selanjutnya adalah evaluasi, yang ditujukan untuk menilai pencapaian tujuan-tujuan yang telah ditentukan serta menilai proses pelaksanaan mengajar secara keseluruhan (Syaodih Sukmadinata, N., 2013, hlm. 110). Sehingga Sudjana, N., mengungkapkan bahwa evaluasi atau penilaian berfungsi (1) untuk mengetahui tercapai tidaknya tujuan pengajaran, dalam hal ini tujuan instruksional khusus; (2) untuk mengetahui keefektipan proses belajar-mengajar yang telah dilakukan guru (Sudjana, N., 1988, hlm 111). Maka dari itu, Sudjana, N., mengelompokan jenis penilaian pada dua kategori yakni tes dan non tes $(1988$, hlm 113).

Kemudian model pembelajaran adalah suatu rencana atau pola yang dapat digunakan untuk membentuk kurikulum (rencana pembelajaran jangka panjang), merancang bahan-bahan pembelajaran, dan membimbing pembelajaran di kelas atau yang lain (Joyce dan Weil dalam Rusman, 2013, hlm. 133).

\section{B.METODE PENELITIAN}

Metode penelitian yang digunakan yakni deskriptif kualitatif, sehingga akan di deskripsikan sesuai dengan hasil analisis data yang telah tersaring yang di dapat pada lapangan tempat penelitian. Metode deskriptif adalah suatu metode dalam pencarian fakta status kelompok manusia, suatu objek, suatu kondisi, suatu sistem pemikiran ataupun suatu peristiwa pada masa sekarang dengan interprestasi yang tepat (Sudarmayanti, dkk., 2002, hlm. 33). Metode ini digunakan mengingat hasil penelitian diharapkan dapat memanfaatkan dalam pengajaran kesenian.

Lokasi yang dipilih dalam penelitian ini adalah pendidikan Luar Sekolah (PLS) yakni Api kreatif. Alasan peneliti mengambil lokasi penelitian ini karena sekolah tersebut terdapat kurikulum tersendiri yang dianggap menarik oleh peneliti, sehingga perlu dilakukan pengamatan dan penelitian. Sedangkan instrumen pada penelitian, di buat atas dasar sebagai panduan untuk observasi dan wawancara, serta dokumentasi selama penelitian dilakukan.

Teknik pengumpulan data adalah cara yang di pakai untuk mengumpulkan informasi atau fakta-fakta di lapangan (Poham dalam Prastowo, 2011, hlm. 208). Selanjutnya, teknik pengumpulan data juga sebagai langkah yang paling strategis dalam penelitian karena tujuan utama penelitian adalah mendapatkan data (Sugiyono dalam Prastowo, 2011, hlm. 
208). Dengan demikian, penelitian ini menggunakan pengumpulan data dengan teknik observasi, wawancara, dan dokumentasi.

Data yang dikumpulkan melalui observasi, wawancara, dan studi dokumentasi, dikaji dan dianalisis oleh peneliti untuk mencapai kesimpulan dan menjawab pertanyaan penelitian. Maka dalam penelitian ini, teknik analisis data yang digunakan adalah teknik analisis data; reduction (Reduksi data), display (Penyajian Data) dan conclusion drawing/verivication (Menarik kesimpulan).

\section{C.HASIL DAN PEMBAHASAN}

\section{Hasil}

Hasil penelitian ini, di uraikan dari hal-hal yang di anggap penting, di ambil dari kegiatan observasi dan pengamatan langsung pada sekolah Api Kreatif. Data yang dikumpulkan dengan teknik observasi, wawancara, serta dokumentasi. Sehingga di analisis serta di transkripkan sedemikian rupa dengan menghasilkan uraian sebagai berikut berikut. Sekolah Api Kreatif memiliki struktur organisasi yang terdiri dari penasihat, ketua, dan sekretaris. Kemudian di dukung oleh TIM pengajar dan Peserta Didik. Dengan demikian, maka terbentuklah konsep pembelajaran sebagai berikut.

Kurikulum di sekolah Api Kreatif mengacu dan berbasis pada pendidikan seni, di muat pada kegiatan siswa pada proses pembelajaran dengan objek seni yang ada diligkungannya. Media yang digunakan di ambil dari lingkungan yang mudah di dapat. Konsep mendidik di sekolah Api Kreatif yang bekerjasama dengan tenga pengajar profesional serta tim ahli pada bidangnya, yang ditujukan untuk mendidik siswa di usia 4 sampai dengan 11 tahun.

Konsep utama Api Kreatif dalam mendidik siswa adalah dengan cara mengolah pengalaman emosional siswa dengan menggunakan konsep besar metode kreativitas sebagai upaya untuk membangkitkan rasa ingin tahu, memperkuat inisiatif untuk membangun imajinasi secara personal, memperjelas keinginan-keinginan personal untuk membangun realitas bangunan kreativitas. Cara ini bertujuan untuk mengarahkan siswa ke arah pertumbuhan fisik, kecerdasan, pengolahan rasa dan pembangunan moral yang baik.

PLS Api Kreatif di bawah pimpinan Jaka Falah dan Asmadiyanti, di tinjau dari kurikulumnya terilustrasikan dengan kegiatan langsung. Sehingga di adakan penelitian 
lebih lanjut, akhirnya peneliti menyusun kurikulumnya dengan satu kali pertemuan sesuai dengan fokus materi yang di amati. Berdasarkan proses observasi, wawancara, dan dokumentasi, sehingga peneliti menemukan penyusunan suatu kurikulum yang dapat dilihat sebagai berikut.

Tabel 1

Program proses pembelajaran mengingat, mengarang, dan mengekspresikan

\begin{tabular}{|c|c|c|c|c|c|}
\hline No & Materi & Media & Rambu Kegiatan & Hasil Kegiatan & Indikator \\
\hline 1. & Mengingat & $\begin{array}{c}\text { Instrumen } \\
\text { (MP3) }\end{array}$ & $\begin{array}{c}\text { Siswa meyakinkan } \\
\text { ide yang akan di } \\
\text { transferkan melalui } \\
\text { goresan di atas } \\
\text { kertas }\end{array}$ & $\begin{array}{c}\text { Membuat suatu } \\
\text { pola yang } \\
\text { menyimbolkan } \\
\text { makna }\end{array}$ & $\begin{array}{c}\text { Menstimulus cara } \\
\text { berfikir }\end{array}$ \\
\hline 2. & Mengarang & $\begin{array}{c}\text { Kertas } \\
\text { HVS dan } \\
\text { Pensil }\end{array}$ & $\begin{array}{c}\text { Siswa menuliskan } \\
\text { atau menceritakan } \\
\text { dari hasil karya yang } \\
\text { telah dituangkan } \\
\text { melalui goresan di } \\
\text { atas kertas }\end{array}$ & $\begin{array}{c}\text { Membuat } \\
\text { keterangan/ } \\
\text { deskripsi dari pola } \\
\text { yang telah di buat }\end{array}$ & $\begin{array}{c}\text { Medisiplinan dalam } \\
\text { melakukan } \\
\text { sesuatu }\end{array}$ \\
\hline 3. & $\begin{array}{c}\text { Mengekspres } \\
\text { ikan }\end{array}$ & - & $\begin{array}{c}\text { Siswa } \\
\text { mengumpulkan hasil } \\
\text { dari sebuah ide dan } \\
\text { gagasan }\end{array}$ & $\begin{array}{c}\text { Mengapresiasi hasil } \\
\text { ide dan gagasan } \\
\text { yang di tampilkan }\end{array}$ & $\begin{array}{c}\text { Menumbuhkan } \\
\text { rasa percaya diri } \\
\text { terhadap apa } \\
\text { yang di buat }\end{array}$ \\
\hline
\end{tabular}

Setelah kurikulum atau konsep pembelajaran dari sekolah Api Kreatif telah di deskripsikan, maka di paparkan pula pelaksanaan pembelajarannya. Hal yang harus diperhatikan adalah tujuan yang hendak di capai, antara lain adalah: bahan dari proses pembelajaran, metode, pendekatan, media, serta jenis evaluasi yang digunakan. Tujuan dari pembelajaran ini diharapkan siswa dapat peka dan antusias dengan lingkungan sekitar, serta dapat melihat hal positif yang layak di tiru dari lingkungan sekitar.

Sedangkan bahan ajar yang digunakan yaitu berkaitan dengan kurikulum yang mengacu pada pendidikan yang berbasis pendidikan seni. Sehingga bahan ajarnya tidak begitu diharuskan harus sesuai dengan urutan yang telah di susun. Namun lebih pada melihat situasai dan kondisi anak dengan apa yang telah dilakukan. Bahan ajar lebih pada sebuah karya seni yang juga dapat dilakukan sebagai media pembelajaran. 
Selama proses pembelajaran berlangsung tidak terlepas dari metode, pendekatan, dan media yang digunakan, sehingga dapat di uraikan sebagai berikut. Metode yang di gunakan adalah dengan metode kelenturan, dengan cara memberi kebebasan terhadap siswa untuk merefleksikan dari imajinasinya. Kemudian pendekatan yang dipakai dengan pendekatan yang berkreativitas, dengan cara menstimulus rasa ingin tahu siswa, sehingga melakukan suatu stimulan terhadap siswa. Sedangkan media yang digunakan yakni berupa kertas HVS, pensil, dan pewarna, sebagai alat untuk menuangkan imajinasi yang dimiliki oleh siswa. Selain itu, proses pembelajaran yang telah dilakukan di sekolah Api Kreatif dalam satu kali pertemuan, maka di ilustrasikan sebagai berikut.

Bagan 3

Syntak tahapan pembelajaran

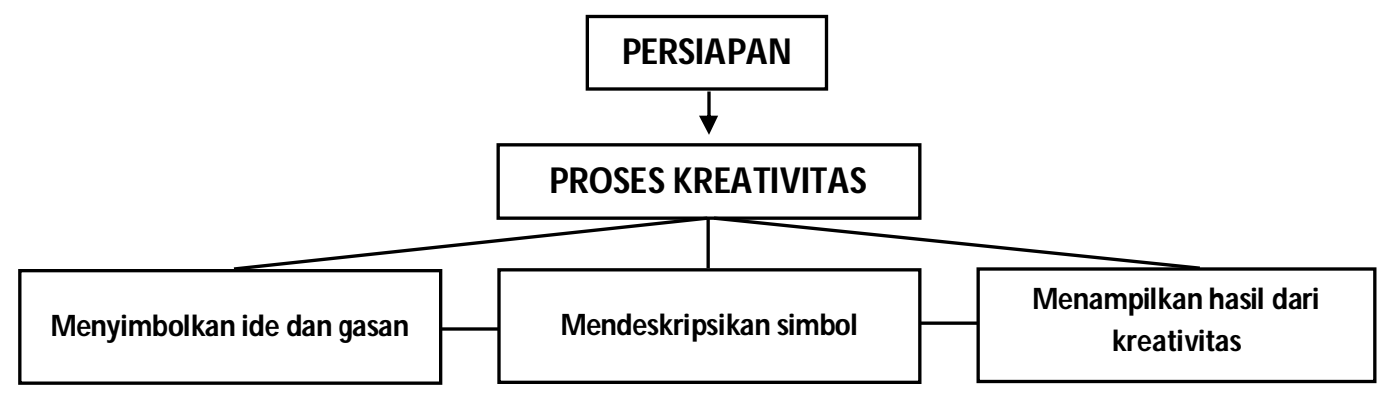

Dari sintak pembelajaran tersebut, sehingga akan diuraikan sebagai berikut:

1) Siswa mempersiapkan peralatan dari proses pembelajaran mengenai pensil, kertas HVS.

2) Siswa mengilustrasikan aktivitas yang ada dalam imajinasinya masing-masing ke dalam bahasa berupa simbol.

3) Siswa menuliskan berupa kalimat dari yang telah di buat atas dasar ilustrasi berupa simbol yang telah di susun.

4) Siswa menampilkan hasil karya untuk diceritakan terhadap teman sekelasnya.

Berdasarkan dari tahapan pembelajaran di atas, sehingga evaluasi pada pembelajaran ini dilakukan dengan tes tertulis, namun tidak menilai dengan angka melainkan di beri simbol yang layaknya mudah dipahami langsung, yakni deangan simbol 
senyum, tertawa, dan cemberut. Mengapa demikian? Karena untuk seni tidak ada salah dan benar layaknya ilmu eksak. Namun karena seni lebih dekat dengan keindahan dan rasa, sehingga evaluasi berupa motivasai dan suport sehingga dari simbol tersebut terdapat makna dari masing-masingnya. Cemberut dalam artian perlu ditingkatkan lagi, senyum silahkan lanjutkan lagi, tertawa mempunyai makna capailah dan teruskan perjuangan agar bisa lebih baik.

\section{Pembahasan}

PLS Api Kreatif merupakan sekolah yang didirikan atas dasar ide dan gagasan Jaka Falah dan Asmadiyanti. Ide dan gagasan tersebut berlandaskan dari pendidikan melalui seni. Pendidikan tersebut melalui kreatifitas anak. Sehingga dari proses kreatifitas dapat dilakukan dengan beragam pola kegiatan yang mengacu pada pengolahan imajinasi yang menghasilkan bentuk yang disalurkan melalui pola-pola dari kreatifitas masing-masing anak. Karya yang dihasilkan dapat berbentuk goresan, tulisan, lukisan, gerakan, dan masih banyak lainnya. Dari bentuk karya yang dihasilkan siswa tersebut tentunya tidak lepas dari bimbingan guru, serta yang paling penting atas semua dukungan atas beridirinya suatu lembaga pendidikan Api Kreatif.

Struktur organisasi pada sekolah Api Kreatif terdapat penasihat dan pelindung, diiringi dengan ketua dan sekretaris, dilengkapi dengan tenaga pengajar, serta tim ahli, dan tentunya terdapat siswa. Maka dari itu dapat diuraikan sebagai berikut. Penasihat dan pelindung berfungsi sebagai orang tua untuk memumpuni dari seluruh rangkaian dan proses kegiatan pembelajaran pada Api Kreatif. Jumlah dari anggotanya adalah sembilan orang, yang memiliki keahlian dan porsi dibidang masing-masing, sehingga dijelaskan sebagai berikut:

1) Ny. Emmy Sariamah Yogie S. Memet, merupakan orang yang memiliki rumah edukasi yakni tempat kesekretariatan pada sekolah Api Kreatif.

2) H. Jeihan Sukmantoro, merupakan pakar seni rupa di bidang pelukis.

3) Mohamad Sunjaya, merupakan seorang tokoh teater atau seniman senior dalam pelakonan dunia pertunjukan teater, yang saat ini juga berdomisili di rumah edukasi (kesekretariatan) Api Kreatif. 
4) Prof. Dr. Sutardjo A.Wiramihardja, S.Psi, merupakan seorang ahli di bidang psikologi, untuk melayani konsultasi dari orang tua tentang siswa.

5) Prof. Drs. Jakob Sumardjo, merupakan seorang budayawan, yang mempunyai konsep bermain ramah dengan lingkungan.

6) Sonny Soeng, merupakan ahli masak (koki), untuk membuat makanan sehat bersama dokter anak.

7) Dra. Hj. Lusi E. Soeria Soemantri, merupakan orang yang sangat berpengaruh pada urusan sosial di kota Bandung.

8) Dr. Tisnasari, Sp.A., merupakan seorang dokter spesialisasi anak dan gizi, sebagai tempat berkonsultasinya siswa dan wali siswa.

9) Dr. Yuliawan Kasmahidayat, M.Si., merupakan dosen UPI yang berkiprah pada pendidikan seni.

Kemudian terdapat pula ketua dan sekretaris yakni sebagai orang yang memiliki ide dan gagasan dasar, serta sebagai orang yang memimpin sekolah Api Kreatif. Selain itu juga sebagai penggegas utama dari terbentuknya suatu lembaga pendidikan Api Kreatif. Selain itu adalah tenaga pengajar, yang saat ini jumlah dari tenaga pengajar masih sangat minim, hanya dua orang yakni Jaka Falah dan Asmadiyanti, juga merangkap sebagai ketua dan sekretaris. Jaka Falah berlatar belakang seni teater, sedangkan Asmadiyanti berlatar belakang seni Tari. Sehingga perannya yakni, memberikan bimbingan terhadap siswa dari seluruh materi yang akan diberikan.

Sedangkan TIM Ahli tidak terbatas jumlah orangnya, bisa ahli dari bidang teater, tari, musik dan rupa. Karena setiap tenaga pengajar memiliki keterbatasan pada pengetahuan bidang seni secara substansial. Sehingga dilakukan tim ahli sebagai tenaga yang melengkapi pengetahuan untuk anak pada siswa dalam proses pembelajaran berlangsung. Sehingga dapat memumpuni dan menyumbangkan ilmu dan pengetahuan pada sekolah Api Kreatif. Kemudian yang tidak dapat dipisahkan dari sebuah organisasi sekolah adalah adanya peserta didik atau siswa. Siswa merupakan objek untuk wahana dalam penyaluran ide dan gagasan yang telah di susun, agar dapat dilihat hasil dan perkembangan dari semua keinginan dan terlaksananya pendidikan pada Api Kreatif. 
Sehingga dari penasihat, ketua/sekretaris, tenaga pengajar/tim ahli maupun siswa menjadi satu kesatuan yang menciptakan suatu terciptanya dan terselenggaranya pendidikan di Api Kreatif tersebut. Maka dapat dikatakan dapat berjalan sesuai dengan konsep yang telah disusun oleh penggegas sekolah tersebut. Dimaknai bahwa komponen dari struktur keorganisasian tersebut merupakan orang-orang berkompetin dan ahli yang produktif sesuai kepakarannya, serta pada porsi masing-masing untuk merealisasikan suatu konsep yang berangkat dari ide dan gagasan yang merujuk pada pendidikan melalui kegiatan berkreativitas seni.

\section{Pelaksanaan dalam Proses Pembelajaran di Sekolah Api Kreatif}

Bahan ajar mengenai segala alat dan media yakni objek dan karya seni seperti hasil karya lukisan orang lain dan diri sendiri, dan lingkungan sekitar. Untuk memperkenalkan dan mengakrabkan diri terhadap alam yang paling dekat. Supaya memudahkan siswa untuk menstimulan daya imajinasinya yang berangkat dari lingkungan paling dekat terlebih dahulu. Sehingga daya dan jembatannya juga akan mudah untuk melanjutkan ke tahap selanjutnya.

Metode yang digunakan yakni seperti membimbing dan memandu, bukan seperti metode pembelajaran yang di kenal pada umumnya (metode ceramah dan lain sebagainya), namun metodenya seperti bermain yang disesuaikan pada usianya. Sehingga di beri keleluawasaan atau kebebasan, dengan demikian mencerminkan terhadap anak agar tetap dapat berfikir kritis untuk tidak membatasi diri, namun tetap pada norma dan aturan layaknya orang yang berakhlak dan berpendidikan. Dapat disimpulkan metode yang digunakan dapat melatih tingkat kecerdasan anak.

Pendekatan di dalam pembelajaran menggunakan siswa untuk dihantarkan dalam sebuah imajinasi mereka, dilanjutkan ke dalam sebuah karya. Kemudian dari karya tersebut mencoba untuk memunculkan kepercayaan terhadap dari apa yang telah dilakukan. Pada akhirnya dapat menumbuhkan rasa tanggungjawab terhadap dari apa yang telah dikerjakan, berdasarkan apa yang telah di buat. Sehingga visi dan misinya untuk membuat anak semakin dan menumbuhkan tanggungjawab yang tiggi. Serta karakter anak banga juga akan terbangun kembali dengan anak yang berkarakter.

Media pembelajaran yakni hasil dari apa yang telah di buat dari siswa tersebut, dengan menggunakan dari apa yang ada dalam imajinasinya. Sehingga menimbulkan 
makna agar meraka tidak melakukan sesuatu tidak berdasarkan dari ide gagasan. Sehingga anak akan terlatih di dalam melakukan sesuatu, harus berdasarkan ide dan gagasan yang matang. Itupun harus sesuai dengan keadaan dan tidak luput dari lingkungan. Dapat dihubungkan dari apa yang kira-kira dapat dilakukan.

Di dalam evaluasi terdapat makna yang melakukan motivasi dan suport terhadap anak bahwa teknik penilaian tidak ada yang salah dan benar, namun tentunya harus tetap pada simbol yang tidak mengurangi motivasi pada anak. Maka yang muncul dari penilaian ini adalah menumbuhkan sikap saling menghargai, sehingga anak tersebut akan tetap menghargai hasil karya siapapun tanpa melihat itu hasil dari siapa dan tidak dilihat dari sisi materi.

\section{Konsep Pembelajaran}

Dari konsep pembelajaran pada satu kali pertemuan yang di amati peneliti, dituangkan menjadi susunan materi, sehingga menghasilkan persepsi yang di susun pada model pembelajaran.

Tabel 2

Konsep materi dan model pembelajaran

\begin{tabular}{|c|c|c|}
\hline NO & MATERI PEMBELAJARAN & MODEL PEMBELAJARAN \\
\hline 1. & Mengingat & Rasa Ingin Tahu \\
\hline 2. & Mengarang & Mengolah Imajinasi \\
\hline 3. & Mengekspresikan & Merefleksikan Imajinasi \\
\hline
\end{tabular}

Dari suatu kurikulum atas dasar analisis tersebut, dapat dilihat pada syntak pembelajaran sebagai berikut:

\section{Bagan 4}

Syntak Model Pembelajaran mengingat, mengarang, dan mengekspresikan

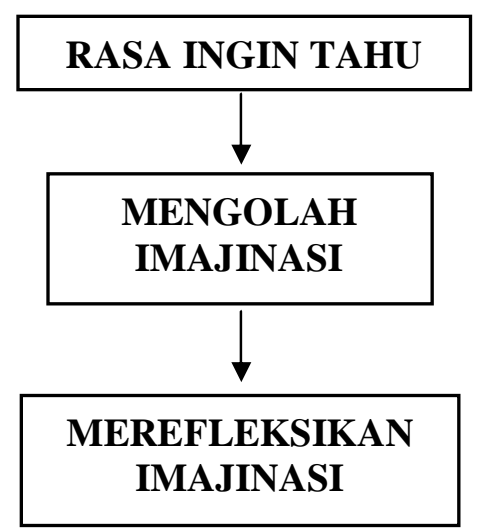


Dari model pembelajaran tersebut sehingga akan di bahas yang diiringi dengan kegiatan pembelajaran yang telah disusun sebelumnya.

\section{Rasa Ingin Tahu}

Melalui rasa ingin tahu, siswa di instruksikan untuk mengingat sesuatu yang ada dalam benak dan fikirannya, dengan cara meyakinkan ide yang akan di transferkan melalui goresan di atas kertas. Untuk menstimulan siswa dapat lebih jernih dan nyaman sehingga di gunakan audio berbentuk musik instrumen yang sesuai dengan gaya tarik pikat, dari pemikiran yang akan di ambilnya. Setelah siswa yakin dengan ide dan gagsannya, maka akan di transferkan melalui pola-pola karya yang sederhana dari masing-masing anak, dengan memaknai dari ide dan gagasan yang diilustrasikan pada simbol yang di polakan tersebut. Dengan kegiatan tersebut, sehingga anak diharapkan dapat terstimulan dari sisi berfikir yang baik.

Kegiatan yang dilakukan untuk mencapai indikator sejauh mana daya ingat siswa untuk dituangkan dalam sebuah karya dengan media yang sederhana. Sehingga siswa mendapatkan proses yang begitu berarti, dalam memikirkan sesuatu sebaiknya harus dengan matang, dan perlu kehati-hatian. Maka mencerminkan sikap berfikir yang mengutamakan kejujuran, terutama berawal dari diri sendiri.

\section{Mengolah Imajinasi}

Melalui tahapan mengolah imajinasi, siswa di instruksikan untuk menuliskan atau menceritakan melalui keterangan yang mendeskripsikan pola yang telah di buat dari kertas yang telah disiapkan. Dengan kegiatan tersebut, sehingga anak diharapkan dapat mengambil kesimpulan yang baik/ sisi positif yang dapat di ambil dari kegiatan tersebut.

Kegiatan yang dilakukan menghasilkan indikator anak dapat membuat suatu karya atas dasar pemikiran yang matang dan berdasarkan ide dan gagasan. Sehingga makna yang dihasilkan yakni, melatih dan melakukan tingkat kedisiplinan di dalam melakukan sesuatu.

\section{Merefleksikan Imajinasi}

Melalui tahapan merefleksikan imajinasi, siswa mengumpulkan hasil kegiatannya, yang akan di eksplorasi melalui berbagai macam ekspresi. Tergantung anak memilih ekspresi apa yang di sukai. Dari kegiatan tersebut siswa diharapkan dapat disiplin dalam berkreatifitas, artinya dapat mempertanggungjawabkan dari apa yang telah di buat. 
Kegiatan yang dilakukan menghasilkan indikator anak dapat percaya diri untuk menampilkan hasil karya di depan orang lain. Sehingga siswa mendapatkan substansi, bahwasanya dalam melakukan sesuatu dapat melakukan pengembangan berfikir. Makna yang muncul adalah melatih siswa agar bisa berdiri sendiri, dan tangguh, serta dapat belajar dewasa yang matang. Sehingga mencerminkan sikap tanggungjawab terhadap dari apa yang telah dibuat dan dilakukan.

Dari kegiatan pembelajaran tersebut, sehingga siswa dapat menghasilkan sesuatu yang bermanfaat dan berdampak positif pada diri sendiri dan orang lain. Sehingga menimbulkan keberanian untuk berfikir, dan berkarya, sehingga dapat berfikir kritis dan memunculkan keperacayaan diri yang tinggi. Sehingga siswa dapat bertanggungjawab dan dapat berkompetisi pada dunia masing-masing di dunia kerjanya kelak. Sehingga karakter dari anak bangsa juga akan mampu menguasai daya saing di dalam tarap nasional bahkan internasional.

Yang di olah dari anak yakni; dari cara berpikir sampai dengan menjadikan sebuah hasil karya dengan pola dia masing-masing, sehingga menimbulkan kepercayaan diri untuk mengembangkan bakat pada dirinya. Tanpa ada paksaan dan tidak di beri ruang yang sempit dalam berfikir. Sehingga anak dapat tumbuh dengan sendiri nya namun tetap di dampingi oleh guru.

Dari ketiga tahapan materi, kegiatan, serta model tersebut, sehingga makna yang dapat di petik yakni menghasilkan inti yang tidak di sadari siswa pada saat mereka melakukan proses kegiatan pembelajaran. Sehingga penulis menyimpulkan, bahwa siswa dapat melakukan hal positif.

\section{Penerimaan Siswa Api Kreatif}

Siswa di Api Kreatif didapatkan melalui promosi dan undangan yang dilakukan dengan menyampaikan informasi melaui brosur dan oral. Itupun dilakukan secara bekerjasama dengan bergotongroyong pada orang-orang sekitar yang ada dilingkungannya. Peran penting dalam informasi siswa baru ini yakni security dari perumahan Suka Mulya, karena rumah edukasi dari tempat kesekretariatan tersebut yakni dirumah komplek Suka Mulya. Dengan demikian security tersebut dengan posisi pos berada disamping rumah eduaksi dari kesekretariatan tersebut. Security melakukan dan 
menyebarkan brosur ke rumah-rumah warga yang ada di komplek suatu perumahan tersebut. Akhirnya terkumpul siswa dengan jumlah 30 orang. Namun ini merupakan langkah awal dari siswa yang ada di PLS Api Kreatif tersebut. Tentunya ada harapan agar siswa tersebut dapat bertambah, tentunya harus berkesesuaian dengan perkembangan sekolah tersebut menjadi lebih besar.

\section{Output Pendidikan Api Kreatif}

Siswa pada proses pembelajarannya diharapkan dapat mengalami segala proses pembelajarannya dengan baik dan dapat mengamati kegiatan dan hasil dari temantemannya yang dapat diambil dari segi positifnya sehingga layak ditiru untuk diterapkan pada kehidupan masing-masing. Hasil akhir yang diharapkan pada proses yang terjadi dalam kegiatan tersebut yakni berkenanan dengan pengelolaan dari kepekaan dan kemauan siswa dalam berfikir dituangkan kedalam sebuah karya kecil untuk menarik dan menstimulan daya kreatifitas anak untuk dapat berkembang. Sehingga siswa akan mulai membiasakan dirinya dengan kehidupan yang berfikir kritis, sehingga dituangkan kedalam sebuah hasil yang nantinya akan dipertanggungjawabkan nantinya ditampilkan depan temannya.

Output yang dihasilkan berdasarkan kurikulum yang dilaksanakan, diharapkan siswa Api Kreatif dapat menjadi siswa yang cerdas, dan dapat berkompetisi pada siswa lainnya. Sehingga siswa tersebut mendapatkan ilmu pengetahuan berkenaan melalui pendidikan seni berkreativitas. Berkreatifitas sehingga mengahsilkan pendidikan dengan melatih siswa untuk mulai menyatukan ide yang ada pada fikirannya, yang menuangkan pada sesuatu yang didapat dituliskan kedalam sebuah pola yang sesuai pada dirinya. Pada akhirnya akan mengahasilkan sebuah karya. Sehingga output yang diharapkan yakni agar siswa mendapatkan wawasan serta rasa sensitivitas untuk menghantarkan ke dunia yang lebih luas untuk mengembangkan sayapnya dihari yang lebih cerah.

\section{Outcome Pendidikan Api Kreatif}

Outcome yang diharapkan pada siswa Api Kretif ini adalah agar siswa tersebut dapat berkompetisi pada siswa lainnya di dunia kerja dimasa mendatang. Siswa Api Kreatif dapat mengemban apapun yang diberikan mengenai tanggungjawab berupa keprofesiannya kelak. Sehingga siswa dapat menjadi orang yang berkarakter, yakni sebagai orang yang dapat mengemban tanggungjawabnya sebagai orang yang 
mempunyai sensitivitas yang tinggi. Sensitifitas yang tinggi dihasilkan dari olah rasa dan latihan cara berfikir didalam pembelajaran berkreatifitas. Sehingga anak-anak dapat mengembangkan sayapnya pada dunia kerjanya. Sehingga anak dapat menjadi siswa yang jujur, disiplin, dan menghargai serta bertanggungjawab pada profesi dan pekerjaan yang diembannya.

\section{Operasional Pendidikan di Api Kreatif}

Pendidikan di sekolah Api Kreatif sudah beroperasional 1,5 tahun. Namun ada hal yang dipandang perlu supaya pendidikan tersebut dapat terealisasi dengan baik. Pandangan peneliti mengenai seluruh rangkaian terciptanya suasana operasional suatu pendidikan di sekolah Api Kreatif tersebut. Dilihat dari tenaga pendidik, ternyata jumlahnya masih sangat minim sekali, yakni hanya dua orang yang merangkap juga sebagai ketua dan sekretaris pada struktur keorganisasiannya. Dipandang perlu oleh penulis bahwa sekolah tersebut dapat berjalan secara lebih produktif apabila tenaga pengajarnya dapat ditambah lagi. Namun tentunya berbagai masalah yang bisa dilihat, yakni dari siswa juga demikian, karena jumlahnya hanya 30 orang, sehingga masih bisa diatasi dengan baik oleh tenaga pengajar dengan jumlah yang minim tersebut. Disamping itu, waktu pembelajarannya disetiap pertemuannya sangat terbatas, dalam satu minggu hanya pada satu kali pertemuan, itupun hanya 2 jam pembelajaran.

Dari uraian tersebut dipandang bahwa jumlah pembelajaran tersebut sangat minim apabila dalam satu kali pertemuan dalam satu minggu. Karena siswa diharapkan akan mendapatkan hal-hal apa saja kalau hanya dengan waktu yang sangat terbatas tersebut. Disamping itu juga mengapa dikatakan kurang efisisen dan produktif karena juga terindikasi bahwa sistem pertemuannya diberikan keleluawasaan terhadap kegiatan siswa waktu di sekolah formal mereka. Dengan demikian kalau di sekolah formal siswa sedang mengadakan ujian semster, sehingga di Sekolah Api kreatif diliburkan. Nah, ini menjadi pandangan perlu bahwa sekolah Api Kreatif masih sangat memberikan tenggangrasa terhadap kebutuhannya di sekolah formal. Sehingga kebutuhan di sekolah Api Kreatif seolah-seolah dikesampingkan. Maka dari itu penulis mempunyai pendapat bahwa alangkah baiknya kalau di sekolah Api Kreatif juga harus mempunyai waktu sendiri yang tidak melihat dengan waktu di sekolah formal. Artinya sekolah Api Kreatif juga mempunyai 
peraturan yang harus disikapi dengan baik supaya operasionalnya dapat berjalan dengan baik dan produktif pula layaknya di sekolah formal.

Dari uraian diatas sehingga dapat diindikasikan, bahwa sekolah Api Kreatif seperti mengalami hal yang sangat rumit pada manajemen material, sehingga mempengaruhi pada minimnya tenaga pengajar yang ada. Bukan hanya itu, namun kelas juga tidak ada, hanya berbentuk aula dan ruangan seperti di sanggar-sanggar yang ada. Kalau hanya seperti itu tentunya tidak jauh berbeda dengan sanggar-sangar yang ada. Padahal suatu sekolah Api Kreatif sudah mempunyai konsep yang baik pada tataran pendidikan melalui seni. Sehingga alangkah lebih baiknya apabila dapat melakukan pemikiran sehingga mendapatkan ekonomis untuk pendukung dalam suatu berjalannya pendidikan di Api Kreatif tersebut.

Dilihat dari program suatu sekolah Api Kreatif, penulis mempunyai angapan bahwa berawal dari sekolah non formal sepertinya akan membangun suatu sekolah yang besar dan akan mengalami transisi ke sekolah formal, seperti TK, ataupun SD. Mengapa demikian? karena dilihat dari sekarang bahwa programnya mulai terlihat konsep yang sangat matang, namun hanya pada pendukung pada materialnya saja yang belum didapatkan dari pihak pemerintah, bahkan dari kerjasama pihak instansi lain yang dapat bekerjasama untuk mendukung supaya operasional pendidikan di Sekolah Api Kreatif dapat berjalan dengan baik dan berkembang. Sehingga dapat disimpulkan bahwa masih sangat minim dimulai dari tenaga pengajar, siswa, bahkan pasilitas lain seperti ruangan dan lainnya.

\section{D.SIMPULAN}

Pendidikan yang dilakukan pada sekolah Api Kreatif mencakup model rasa ingin tahu, mengolah imajinasi, dan merefleksikan hasil imajinasi. Dari sintak pembelajaran tersebut sehingga terjadi proses pembelajaran dengan melakukan tahapan-tahapan dari ide dan gagsan menjadi sebuah karya sehingga ditampilkan depan orang banyak. Pendidikan di sekolah Api Kreatif untuk melakukan dan mengasah kepekaan rasa terhadap siswa, agar menjadi orang yang cerdas, serta bertanggungjawab dari apa yang akan dilakukannya, berbasis pada kegiatan berkreatifitas. Sehingga menghasilkan manusia yang dapat berlaku jujur, adil, disiplin, menghargai, tanggungjawab, serta percaya 
diri. Sehingga akan menimbulkan karakter anak bangsa yang baik untuk mendukung terlaksananya pendidikan Indonesia yang jauh lebih bermartabat.

Saran peneliti untuk lembaga PLS yakni Api Kreatif adalah agar secepatnya mempunyai gedung sendiri layaknya sekolah-sekolah yang ada di Nusantara. Kemudian siswa nya agar dapat ditambah lebih banyak lagi. Tenaga pengajarnya juga demikian agar bisa ditambahkan, dan tidak menutup kemungkinan dapat tercipta sekolah formal dengan tingkat TK dan SD. Namun tentunya tak lepas dari tujuan dari berdirinya sekolah Api Kreatif yakni agar menumbuhkan kepekaan rasa terhadap anak sehingga menjadikan anak yang berkreatifitas, pada akhirnya berkreatifitas pada bidang masing-masing.

\section{Daftar Pustaka}

Hamalik, Oemar. (2009). Kurikulum dan Pembelajaran. Jakarta: Bumi Aksara.

Hamiyah, N., \& Jauhar, M. (2014). Strategi Belajar Mengajar di Kelas. Jakarta: Prestasi Pustaka Raya.

Hamzah, dkk. (2010). Desain Pembelajaran. Bandung: MQS Publishing.

Nazir, Moh. (2005). Metode Penelitian. Bogor: Ghalia Indonesia.

Prastowo, Andi. (2011). Metode Penelitian Kualitatif dalam Perspektif Rancangan Penelitian. Jogjakarta: Ar-ruzz Media.

Rusman. (2013). Model-Model Pembelajaran: Mengembangkan Profesionalisme Guru. Jakarta: PT. Raja Grafindo Persada.

Sudarmayanti, dkk. (2002). Metode Penelitian. Bandung: CV. Mandar Maju.

Sudjana, N. (1988). Dasar-dasar Proses Belajar Mengajar. Bandung: Sinar Baru.

Sugiyono. (2008). Metode Penelitian Kuantitatif Kualitatif dan R \& D. Bandung: Alfabeta.

Susilana, dkk. (2007). Media Pembelajaran. Bandung: CV. 